\author{
Edyta Sacharewicz \\ Kolegium Literaturoznawstwa \\ Wydział Filologiczny \\ Uniwersytet w Białymstoku \\ e-mail: e.sacharewicz@uwb.edu.pl \\ ORCID: 0000-0002-4069-2975
}

\title{
Raj utracony, czyli obraz Afryki w powieściach J.M.G. Le Clézio: Onitsza oraz Afrykanin
}

\section{Wstęp}

Badacze eksplorujący temat raju jako metafory wymarzonej krainy, w której człowiek pragnie się znaleźć, nie mogą pominąć twórczości J.M.G. Le Clézio. Ten obywatel świata, który całe życie podróżował, aby zrozumieć, kim jest i kim są inni oraz odnaleźć prawdziwy dom, w swoich utworach naszkicował poetycki obraz miejsc zbudowany z mitów oraz marzeń różnych kultur. Osobista historia pisarza wyjaśnia jego potrzebę odkrywania i poznawania innego: brytyjski obywatel, urodzony w Nicei oraz wychowywany w wielokulturowej rodzinie, związanej korzeniami z byłą kolonią francuską - Mauritiusem. Obcowanie z innymi kulturami od wczesnych lat dzieciństwa wpłynęło na dorosłe życie Le Clézio, ciągłą potrzebę podróżowania i odnalezienia własnego miejsca na ziemi. W jednym $\mathrm{z}$ wywiadów cytowanych przez Bruno Thibaulta, Le Clézio wyznaje:

Sam siebie postrzegam jako wygnańca, ponieważ moja rodzina była całkowicie maurytyjska. Od pokoleń byliśmy karmieni folklorem, kuchnią, legendami oraz kulturą maurytyjską. To bardzo wymieszana kultura, w której łączą się Indie, Afryka, Europa. Urodziłem się we Francji, ale zostałem wychowany w tamtej właśnie kulturze. Dorastałem, powtarzając sobie, że jest jakieś inne miejsce, które uosabia moją prawdziwą ojczyznę. Pewnego dnia pojadę tam i dowiem się, co to za miejsce. We Francji nie do końca jestem mile widziany. Kocham ję- 
zyk francuski, który być może jest moją prawdziwą ojczyzną! Ale jeśli postrzegamy Francję jako naród, to muszę przyznać, że rzadko utożsamiałem się z jego zasadami ${ }^{1}$.

Tajemnice Afryki, która zajmuje szczególną pozycję w jego życiu oraz twórczości, pisarz odkrył już we wczesnych latach dzieciństwa, kiedy to przeprowadził się wraz z matką do Nigerii. Również małżeństwo z Jemią, Marokanką, z którą podróżował po rodzinnych stronach żony, wpłynęło na jego zainteresowania. Pisarstwo Le Clézio przesiąkło tymi doświadczeniami, a afrykański kontynent stał się bohaterem takich powieści, jak: Désert (1980, wyd. polskie - Pustynia, 1985), Onitsha (1991, wyd. polskie - Onitsza, 1995), Gens des nuages [Ludzie z chmur] (1997), Poisson d'or [Złota rybka] (1997) czy L’Africain (2004, wyd. polskie - Afrykanin, 2008).

Celem niniejszego artykułu jest przedstawienie obrazu Afryki jako krainy szczęśliwości, do której podążają bohaterowie powieści Onitsza oraz Afrykanin, by odnaleźć spokój. Główna część pracy zostanie poprzedzona krótką analizą motywu „raju utraconego" w twórczości francuskiego noblisty.

\section{Raj utracony jako lejtmotyw pisarstwa Le Clézio}

Mit raju utraconego jest obecny w kulturze, $\mathrm{w}$ rozważaniach na temat kondycji człowieka od bardzo dawna. Liczne cywilizacje wierzyły w pierwotny raj, gdzie panowały doskonałość, wolność, pokój, szczęście, obfitość wszystkiego, brak przymusu czy konfliktów. Ludzie rozumieli się wzajemnie i żyli w zgodzie ze zwierzętami. W zbiorowej świadomości rodziła się wielka tęsknota za rajem utraconym, ale niezapomnianym oraz ogromna potrzeba, aby go odzyskać ${ }^{2}$. Wydaje się, że najbardziej znaną wersją tego mitu jest opowieść biblijna. Adam i Ewa zostali wygnani z Ogrodu Eden, miejsca wszelkiej szczęśliwości, gdzie nie było bólu i cierpienia. Prawdą jest natomiast, iż mnogość sensów, które niesie ze sobą ten motyw, nie pozwala na podanie jednej, konkretnej definicji raju. Z pewnością jednak łączy je wszystkie tęsknota za doskonałością, która jest wyrazem marzenia o idealnym życiu. Samo określenie lokalizacji raju otwiera całe spektrum możliwości. Jerzy Prokopiuk zauważa, że mógł on się znajdować zarówno w „świecie podziemnym” czy w dalekim rejonie Ziemi (np. na Wschodzie lub na Zachodzie), ale także na

1 B. Thibault, J.M.G. Le Clézio et la métaphore exotique, Amsterdam 2009, s. 9 [tłum. - E.S.].

2 J. Delumeau, Historia raju, przeł. E. Bąkowska, Warszawa 1996, s. 10. 
jakiejś „wyspie” lub "górze” (jako podporze Nieba) czy być „krainą przodków”. Z drugiej strony jego „miejscem” mógł być Księżyc, różne planety, Słońce czy wreszcie gwiazdy (niekiedy uważane także za przemienionych zmarłych) ${ }^{3}$.

Bogata twórczość Le Clézio ${ }^{4}$ jest również przesiąknięta myślą znalezienia idealnego miejsca, w którym można by było wieść szczęśliwe życie. Atéba Mbassi twierdzi, iż ślady poszukiwań korzeni oraz raju utraconego są obecne we wszystkich utworach pisarza ${ }^{5}$. Z kolei Jean Onimus mówi o powrocie do utraconego raju jako lejtmotywie jego twórczości ${ }^{6}$. Vidoolah Mootoosamy podkreśla jednak, że wizja krainy wiecznego szczęścia, przedstawiona przez autora $\mathrm{w}$ poszczególnych utworach, różni się między sobą. Powieści, które powstały $\mathrm{w}$ pierwszym etapie twórczości Le Clézio przywołują obraz raju w nieoczywisty sposób. Bohaterowie chcą uciec od miejskiego świata, nie mają jednak konkretnej wizji miejsca, w którym mogliby odnaleźć spokój. Poszukiwania poszczególnych postaci są skazane na niepowodzenie, a ich przeznaczenie to ciągła wędrówka, prowadząca do szaleństwa lub, co gorsza, do śmierci7 ${ }^{7}$ Tak jest m.in. w powieści La Guerre (1970, Wojna), w której bohaterka, Bea B., codziennie wędruje po mieście, przypatrując się otaczającej ją rzeczywistości. Jest obserwatorką wojny, która, według niej, trwa od początku istnienia ludzkości. Dziewczyna szuka miejsca, gdzie byłaby bezpieczna, lecz nie odnajduje go nawet w miłości. Stwierdza gorzko: „przed wojną nie ma ucieczki"8.

Wyobrażenia pisarza dotyczące krainy szczęśliwości, pojawiające się w drugim etapie twórczości, są ściśle powiązane z jego podróżami oraz długimi pobytami wśród Indian z Meksyku. Pod wpływem tego doświadczenia autor odkrywa inny styl życia, bazujący przede wszystkim na harmonii wytworzonej między człowiekiem a naturą. Nowy obraz raju to nieskażona, dzika przyroda, którą możemy odnaleźć także we współczesnej rzeczywistości. Każda powieść nawiązuje do miejsca pozwalającego się mniej lub bardziej precyzyjnie zlokalizować na mapie, np. centrum Meksyku w Uranii, Ziemia Obiecana w Étoile errante czy wyspa Mauritius w Poszukiwaczu złota9. Te idyl-

\footnotetext{
3 J. Prokopiuk, Mit Raju, „Konteksty” 1994, nr 3-4, s. 5.

4 Le Clézio jest autorem ponad 30 książek.

5 A. Mbassi, Identité et fuidité dans l'œuvre de Jean-Marie Gustave Le Clézio, Paris 2008, s. 23.

6 J. Onimus, Pour lire Le Clézio, Paris 1994, s. 55.

7 V. Mootoosamy, "Maurice est si loin qu'on ne peut qu'en rêver": le Paradis perdu de J.M.G. Le Clézio entre mythe et memoire, „Altre Modernità" 2012, nr 7, s. 112, https:// riviste.unimi.it/index. php/AMonline/article/view/2140 [dostęp 24.04.2019].

8 J.M.G. Le Clézio, Wojna, przeł. K. Teodorowicz, Warszawa 2010, s. 306.

9 Tamże, s. 113.
} 
liczne krainy, chociaż różnorodne, mają jedną wspólną cechę: wszystkie są położone poza Europą. Takie wyjątkowe miejsce Le Clézio odkrywa również podczas swojej wyprawy do Afryki, odbytej w dzieciństwie.

\section{Afrykański raj utracony}

Motyw podróży na kontynent afrykański pojawia się po raz pierwszy w Onitszy. Tytułowa Onitsza to nazwa portu rzecznego nad Nigrem, miejsce, do którego przyjeżdżają kilkunastoletni Fintan i jego matka Maria Luisa, zwana Maou, by po wielu latach rozłąki zamieszkać z ojcem chłopca, Geoffroyem Allenem. Wyprawa do tego odległego zakątka ziemi budzi w Maou ogromne nadzieje, gdyż $\mathrm{w}$ końcu będzie mogła połączyć się z ukochanym mężczyzną. Zaś chłopiec, któremu kontynent był znany do tej pory jedynie $\mathrm{z}$ baśniowych opowieści matki, ma mieszane uczucia. Lęk rodzący się w młodzieńczym sercu łączy się $z$ fascynacją oraz zniecierpliwieniem. $Z$ jednej strony Fintan boi się zamieszkać z ojcem, którego nigdy nie poznał, z drugiej zaś strony nie może się doczekać, by zanurzyć się w nieznany świat, przyciągający go do siebie niczym magnes:

Fintan czuł, jak rośnie w nim niecierpliwość. Chciał dotrzeć tam, do tego portu u kresu podróży, na końcu wybrzeża Afryki. Chciał zatrzymać się, wejść w ciemną smugę wybrzeża, przebyć rzeki i lasy, aż do Onitszy. To była magiczna nazwa. Nazwa przyciągająca jak magnes. Nie można było jej się oprzeć. „Kiedy będziemy w Onitszy..." Maou tak mówiła. Była to nazwa bardzo piękna i bardzo tajemnicza, jak las, jak zakręt rzeki. Babka Aurelia miała w swoim pokoju w Marsylii, nad wysoko zasłanym łóżkiem, obraz przedstawiający polanę w lesie, na której odpoczywa stado jeleni. Za każdym razem, kiedy Maou mówiła o Onitszy, Fintan myślał, że musi tam być tak właśnie, jak na tej polanie, gdzie zielone światło sączy się przez listowie ogromnych drzew ${ }^{10}$.

Pierwsza afrykańska podróż jest realizacją chłopięcego marzenia, wyprawą do świata wyobraźni. Po przybyciu na miejsce wizja Afryki, wykreowana na podstawie opowiadań Maou, dla której kontynent jawił się jako swoista Arkadia, zostaje zderzona z rzeczywistością, a ojciec, skoncentrowany na szukaniu bóstw i skarbów kultury afrykańskiej, wydaje się zupełnie obcym człowiekiem. Z czasem Fintan godzi się z nowymi realiami, a Afryka staje się dla niego symbolem prawdziwego życia. Miejsce to nie ma

10 J.M.G. Le Clézio, Onitsza, przeł. A. Paderewska-Gryza, Warszawa 2008, s. 39-40. Kolejne cytaty lokalizuję w tekście głównym, oznaczając je literą O. 
nic wspólnego z ciasnym mieszkaniem, gdzie żył zamknięty w czasie wojny, ani z wąskimi ścianami angielskiej szkoły, w której kończył edukację. Chłopiec nigdy wcześniej nie widział takiej przestrzeni, jak w Onitszy: szeroka niczym morze rzeka, rozległe plaże, plantacje palm, sawanny, to wszystko tworzy zróżnicowany i zaskakujący świat, który Fintan powoli, lecz zachłannie odkrywa, biegając na bosaka po trawiastych równinach. Tysiące nowych wrażeń obezwładniają młodego Europejczyka: zapach „zapylonej ziemi, bardzo niebieskiego nieba, lśniących palm, białych domów" [O, s. 26], który jest wszędzie, w wietrze, we włosach, w ubraniu, a nawet w słońcu, jak wspomina bohater [O, s. 28]. W tym świecie licznych doznań, Fintan w naturalny sposób odkrywa również nagość kobiecego ciała, a nawet asystuje przy narodzinach dziecka:

Odwróciła się nagle w jego stronę, spojrzała nań, on zaś przysunął się bliżej. Ściskała dłoń Fintana, miażdżąc ją prawie. On także musiał coś zrobić, uczestniczyć w narodzinach. Nie czuł bólu ręki. Słuchał, patrzył na to niezwykłe wydarzenie. W kadłubie "George’a Shottona" coś się pojawiło, wypełniało przestrzeń, rosło, tchnienie, woda występująca z brzegów, światło. Serce Fintana tłukło się w nim aż boleśnie, gdy fala przepływała przez ciało Oyi, odrzucała jej twarz do tyłu. Dziewczyna otwierała usta, jak po wynurzeniu się z wody. Nagle wydała krzyk i wypchnęła na ziemię dziecko podobne do czerwonej gwiazdy w obłoku łożyska [O, s. 168].

Tak nagłe i pełne emocji doświadczenia pozwalają chłopcu odkryć tajemnicę świata i życia. Podróż do Afryki okazuje się ważnym etapem $\mathrm{w}$ dojrzewaniu dziecka, swoistą inicjacją w dorosłośćc ${ }^{11}$. Fizyczna oraz psychiczna przemiana bohatera: nauka nowego języka, nowe przyjaźnie oraz sposób zachowania nadają mu nową tożsamość. Z czasem Fintan czuje się tak, jakby „urodził się tutaj, nad tą rzeką, pod tym niebem, że zawsze to znał" [O, s. 154], a ludzie, którzy go otaczają byli jego prawdziwą rodziną. Ugo, babka jego przyjaciela Bony'ego, nazywa go „umu, jakby także był jej synem. Fintan myślał czasem, że to rzeczywiście jego rodzina, że jego skóra stała się jak skóra Bony'ego, czarna i gładka" [O, s. 153]. Françoise Ugochukwu zwraca uwagę również na przemianę zachodzącą w zachowaniu Maou, która, z początku rozczarowana nowym życiem, coraz bardziej identyfikuje się z mieszkańcami Onitszy, nawiązuje przyjaźnie z miejscowymi kobietami,

11 F. Ugochukwu, L'Étranger chez Le Clézio: une exploration d'Onitsha et de L'Africain, w: L'Étranger, red. A. C. Santos, M. de Jesus Cabral, Editions Le Manuscrit, Paris 2016, s. 5, https://www. academia.edu/28415163/LEtranger_chez_Le_Clézio_une_exploration_dOnitsha_et_de_LAfricain [dostęp 21.04.2019]. 
uczy się ich języka ${ }^{12}$ : „Maou [...] stała się kimś innym. Wszystko, co przeżyła przed Onitszą, Nicea, Saint-Martin, wojna, oczekiwanie w Marsylii, wszystko to stało się obce i odległe, jak gdyby przeżył to ktoś inny. Teraz należała do rzeki, do tego miasta" [O, s. 125].

Losy Fintana mieszają się z wątkiem bardziej onirycznym, związanym $z$ legendą o Meroe, czarnej egipskiej królowej, i jej ludzie, uznanych za heretyków wyznawców Atona, którzy musieli uciekać ze swej ziemi, by, zgodnie z wizją wyroczni, znaleźć podobne miejsce. Ich wędrówka przypomina zmierzanie do własnej Ziemi Obiecanej, którą odnajdują nad rzeką Niger. Historia ta jest przedmiotem zainteresowań ojca Fintana, który poświęcił lata, by podążać śladami zaginionej cywilizacji. Marzenie o jej odnalezieniu staje się jego obsesją i oddala go od rodziny. Wszystko się kończy, gdy Geoffrey Allen zapada na czarną malarię i musi walczyć o życie. Mężczyzna pojmuje, że „raju nie ma" [O, s. 174], "droga z Meroe zagubiła się w piasku pustyni” [O, s. 191], a to, co najważniejsze ma obok siebie.

Afryka otwiera bohaterów Onitszy na nową kulturę, uczy doceniać spokój oraz naturę, ale przede wszystkim w magiczny sposób pozwala zjednoczyć się rodzinie.

Trzynaście lat później Le Clézio podejmuje raz jeszcze te same wątki, opisuje identyczne szczegóły, jednakże tym razem odrzuca fikcyjną, powieściową formę. W autobiograficznym utworze Afrykanin pisarz powraca do czasów dzieciństwa spędzonego w Afryce. Opowieść Le Clézio rozpoczyna od opisów ciał, które go otaczają natychmiast po przybyciu na Czarny Ląd:

Ciało matki, mojego brata, ciała chłopców z sąsiedztwa, z którymi się bawiłem, ciała afrykańskich kobiet na drogach, wokół domu albo na targu, nieopodal rzeki. Ich sylwetki, ciężkie piersi, lśniąca skóra na grzbiecie. Członki chłopców z różowym obrzezanym żołędziem. Twarze na pewno też, ale podobne do stwardniałych, pokrytych bliznami i rytualnymi znakami skórzanych masek. Sterczące brzuchy, guziki pępka podobne do kamyka wszytego pod skórę. Także zapach ciał, dotyk, skóra nie szorstka, lecz ciepła i delikatna, najeżona tysiącami włosków ${ }^{13}$.

Marija Panic zauważa, iż słowo „ciało"14, od którego zaczyna się powieść, staje się elementem centralnym całej historii ${ }^{15}$. Wszechobecna swo-

12 F. Ugochukwu, L'Étranger chez Le Clézio: une exploration d'Onitsha et de L'Africain, s. 7.

13 J.M.G. Le Clézio, Afrykanin, przeł. K. i K. Pruscy, Warszawa 2008, s. 8. Kolejne cytaty lokalizuję w tekście głównym, oznaczając je literą A.

14 Ciało to również tytuł pierwszego rozdziału książki, co podkreśla znaczenie tego słowa.

15 M. Panic, Le continent énigme: l'Afrique vue par les yeux de Kourouma et de Le Clézio, http:// www.fabula.org/colloques/document1340.php [dostęp 14.04.2019]. 
boda autochtonów w pokazywaniu nagości wywiera na młodym chłopcu duże wrażenie, jest czymś nowym, staje się symbolem kraju, do którego właśnie przybył, symbolem wolności. We Francji, gdzie dotychczas żył z babką, matką i bratem, w lustrze oglądał swoją twarz, która jako jedyna, nie licząc dłoni, wynurzała się ze szczelnie zapiętego ubrania. Tu zauważył swoje ciało - najpierw rozgorączkowane upałem i słońcem, potem obolałe od otarć i ugryzień. Dostrzegł naturalność nagości.

Afryka to także ogromna przestrzeń i potęga natury. Le Clézio opisuje liczne zdarzenia, których doświadcza od samego początku swojego pobytu na afrykańskim kontynencie, pokazujące siłę natury, z którą obcuje - poczynając od bolesnych przeżyć, jakich dostarczyło mu poparzone $\mathrm{z}$ powodu upału, pokryte licznymi pęcherzykami ciało, a kończąc na potężnych zjawiskach przyrodniczych:

Burze, jakich nigdy potem nie widziałem nawet $\mathrm{w}$ najśmielszych snach, atramentowe niebo posiekane błyskawicami, wiatr, który giął wielkie drzewa wokół ogrodu i zrywał liście z dachu, wdzierał się pod drzwiami i wirując gasił lampy naftowe $\mathrm{w}$ jadalni. $\mathrm{W}$ niektóre wieczory nadciągał czerwony wiatr $\mathrm{z}$ północy, od którego skrzyły się ściany [A, s. 15].

Afryka pokazuje mu swoje nieokiełznane, agresywne i nieprzewidywalne oblicze. Przemoc obecna w przyrodzie, utożsamiana $\mathrm{z}$ kontynentem afrykańskim, jest inna niż ta, której Le Clézio doświadczył w Europie. Jak sam pisze:

Pamiętam przemoc. Nie przemoc skrywaną, obłudną, budzącą grozę, znaną wszystkim dzieciom urodzonym $\mathrm{w}$ środku wojny [...] tamta przemoc nie była tak naprawdę fizyczna. Raczej przygłuszona i ukryta jak choroba [...]. Ogoja ofiarowywała mi inną przemoc, otwartą, namacalną, wprawiającą ciało $\mathrm{w}$ drżenie [A, s. 14-15].

Ta namacalność wrażeń świadczy o pełnej swobodzie ciała i ducha. Wychowany $\mathrm{w}$ domu pełnym konwenansów, gdzie wymagano przede wszystkim odpowiednich manier, młody Le Clézio otrzymał w prezencie wolność nie tylko od ubrania, lecz także od karcących spojrzeń babć i ciotek. Afryka stała się dla niego wybawieniem, miejscem, gdzie zaczynają się spełniać prawa dzieciństwa. Daje autorowi poczucie totalnej wolności oraz swobody w takim natężeniu, że „parzyła, upajała, dawała rozkosz aż do bólu" [A, s. 101].

Jednakże Afryka w Afrykaninie to przede wszystkim ojciec, do którego odnosi się tytuł książki. Pisarz tak wspomina ich pierwsze spotkanie: 
Mężczyzna, którego spotkałem w 1948, roku moich ósmych urodzin, był zniszczony, przedwcześnie postarzały w równikowym klimacie, nadpobudliwy z powodu teofiliny łagodzącej ataki astmy, zgorzkniały w skutek samotności wojennych lat przeżytych w odcięciu od świata, bez wiadomości od rodziny, bez możności opuszczenia posterunku, pospieszenia z pomocą żonie i dzieciom ani nawet wysłania im pieniędzy [A, s. 37].

Ojciec okazał się człowiekiem dość surowym i zasadniczym. Mimo tego autor zapamiętał go przede wszystkim jako osobę całkowicie oddaną swojej pracy i daleką od konformizmu kolonistów. Afryka stała się dla niego przybraną ojczyzną. Po przejściu na emeryturę mężczyzna wraz z rodziną powrócił do Francji. Nie czuł się jednak Europejczykiem, gdyż za bardzo identyfikował się z Czarnym Lądem. Do końca swoich dni wspominał ukochany zakątek ziemi i snuł plany o wyjeździe. Niestety nigdy ich nie zrealizował.

Ojciec staje się bardzo ważną postacią w życiu pisarza, gdyż to właśnie on wpływa na jego wrażliwość i sposób postrzegania świata. Dlatego też dla Le Clézio Afryka to nie tylko egzotyczny zakątek, piękne krajobrazy i dzikie zwierzęta, ale też miejsce, z którym czuje duchową więź, które obdarzył głębokim uczuciem przywiązania. Emocje, jakie wzbudzała Afryka zarówno w ojcu, jak i synu, pozwoliły im zbliżyć się do siebie.

Obraz afrykańskiego dzieciństwa przepełnionego wolnością zostaje zburzony przez brytyjskie rządy kolonialne. Europejscy urzędnicy są ukazani jako ludzie wywyższający się, nietolerujący niekonwencjonalnych zachowań, którzy postrzegają „społeczeństwo afrykańskie jako raz na zawsze ustaloną hierarchię, gdzie każdy powinien wypełniać swoją rolę" [O, s. 129]. Takie podejście jest obce bohaterom obydwu powieści. Maou nie godzi się na złe traktowanie niewolników podczas przyjęcia w domu Geralda Simpsona i otwarcie manifestuje swój gniew na widok takich praktyk:

Na końcu ogrodu, przy siatce służącej za ogrodzenie, Murzyni prażyli się w słońcu, pot skrzył się na ich plecach, na ramionach. Słychać było wciąż ich ciężki oddech, jęk bólu za każdym razem, kiedy uderzali w ziemię. Maou zerwała się nagle i głosem drżącym od gniewu, swoim akcentem francusko-włoskim, który dziwnie brzmiał, kiedy mówiła po angielsku, powiedziała: - Ale trzeba dać im jeść i pić, spójrzcie, ci biedacy są głodni i spragnieni! [O, s. 65]

Jej niezależność spotyka się z dużym niezadowoleniem ze strony europejskich znajomych. Także Geoffrey Allen nie boi się okazać pogardy systemowi kolonialnemu. To wszystko sprawia, że cała rodzina zostaje zmuszona do opuszczenia ukochanego miejsca. Fintan, po latach spędzonych w Europie, gdzie powrócił wraz ze swoimi rodzicami, dowiaduje się o trudnej 
sytuacji Afryki oraz jej mieszkańców pod koniec rządów kolonialnych. Okrucieństwa wojny domowej, cierpienia związane z suszą oraz głodem doprowadziły do śmierci tych, pośród których żył i których traktował jak rodzinę. Chłopiec zdaje sobie sprawę, że to magiczne miejsce, w którym spędził najlepsze lata swojego dzieciństwa, zostało bezpowrotnie utracone: „Wszystko jest skończone. W Umahia, w Abie, w Owerii wygłodniałe dzieci nie mają już siły trzymać broni. Zresztą miały już tylko kije i kamienie przeciwko samolotom i działom [...]. Cały świat odwraca oczy" [O, s. 221]. Ta wizja utraconego raju nie daje mu spokoju, nocami śni o tym wszystkim, co zostało zniszczone. Swój żal oraz tęsknotę wyraża w liście do siostry Marimy, opisując zapamiętaną Onitszę, by również i ona mogła poczuć namiastkę tego, co przeżył.

W Afrykaninie pisarz również poświęca uwagę ciemnej stronie pobytu Europejczyków w Afryce. Podkreśla, iż jego ojciec żywił głęboką nienawiść do kolonializmu „pod każdą postacią” [A, s. 93]. Pracując jako lekarz i podróżując, czasem nawet całymi dniami, do oddalonych wiosek, ojciec pisarza odczuwał niejednokrotnie dyskomfort, gdy widział strach w oczach pacjentów. Musiał zaakceptować fakt, iż nie był dla Afrykanów „ich krewnym, przyjacielem" [A, s. 82], osobą, która niesie ulgę w cierpieniu, lecz jedynie "kolejnym przedstawicielem kolonialnej władzy" [A, s. 82].

Le Clézio nie pomija wydarzeń, jakie miały miejsce w Afryce po jego powrocie do Europy i powoli niszczyły kraj, który tak ukochali z ojcem: wojny plemienne, AIDS, a przede wszystkim wojna o Biafrę ${ }^{16}$. Za zaistniałą sytuację pisarz obwinia zachodnie mocarstwa: Francję, Anglię, Stany Zjednoczone, które pozostawiły wyeksploatowaną Afrykę na pastwę losu.

\footnotetext{
16 Głównym problemem Nigerii, z jakim zmagała się po dekolonizacji w 1960 r., było utrzymanie jedności. Nigeria weszła w niepodległość z konstytucją, która podzieliła kraj i jego obywateli na trzy regiony. Każdym rządziła partia reprezentująca większość jego mieszkańców: jednym Hausa i Fulanie, drugim Jorubowie, trzecim Ibo. Każda z głównych partii usiłowała kierować swoim regionem tak, jakby był oddzielnym krajem, a poszczególne rządy regionalne domagały się coraz większej swobody w podejmowaniu decyzji w sprawach takich jak handel i przemysł. W 1967 r. przywódcy Ibo, żyjący we wschodnim regionie, ogłosili powstanie niezależnej republiki Biafra. Lokalni politycy oskarżali władze w Lagos o marginalizację ekonomiczną regionu, pozbawianie Ibo stanowisk państwowych i inicjowanie pogromów na zislamizowanej północy kraju. Wkrótce wybuchła wojna. Po trzech latach Biafrańczycy musieli skapitulować przed wspieranymi przez Brytyjczyków wojskami federalnymi. W trakcie konfliktu zginęło ok. miliona Nigeryjczyków. Większość z nich stanowiły ofiary głodu w Biafrze, katastrofy humanitarnej związanej z blokadą ekonomiczną, zniszczeniami w sektorze rolnym oraz rozkradaniem środków pomocowych przez obie strony konfliktu [zob. B. Davidson, Społeczna i polityczna historia Afryki XX w., przeł. B. Hlebowicz, Warszawa 2011, s. 197].
} 


\section{Konkluzje}

Afryka, która odegrała wyjątkową rolę w życiu oraz twórczości Le Clézio, była nie tyle przestrzenią akcji, co „bohaterem” dwóch jego utworów: Onitszy oraz Afrykanina. Francuski autor dzieli się w nich swoją pasją do miejsca, które, po smutku i lękach wojennych przeżytych w Europie, stało się dla niego oraz protagonistów jego powieści (choć na chwilę) prawdziwym domem.

Obraz kontynentu przedstawiony w obu powieściach jest subiektywną wizją pisarza. $Z$ jednej strony Afryka ukazana została jako miejsce magiczne, utożsamiane $\mathrm{z}$ nieograniczoną swobodą oraz wolnością. Kontynent ten zachwyca różnorodnością oraz niezwykłymi zjawiskami przyrodniczymi. Z drugiej zaś, doświadczanie „cielesności”, wszechobecna przemoc przyrody, oschłość ojca wobec syna czy też rządy kolonialne kładą cień na beztroski obraz dzieciństwa. Nadzieje bohaterów na odnalezienie krainy, w której mogliby wieść szczęśliwe życie, zostają zburzone.

Nie ma jednak wątpliwości, iż kontynent ten fascynuje autora, a oba utwory stają się hołdem złożonym niezwykłemu miejscu, które głęboko i trwale wpłynęło na pisarza. Jak sam wyjaśnia: „Dzisiaj istnieję, podróżuję, założyłem własną rodzinę, zapuściłem korzenie w innych miejscach. Mimo to $\mathrm{w}$ każdej chwili przenika mnie niegdysiejszy czas, tamten z Ogoja, jak eteryczna substancja krążąca w tkance rzeczywistości" [A, s. 102]. Le Clézio na zawsze zachował w pamięci obraz Afryki jako raju, który został bezpowrotnie utracony.

\section{Bibliografia}

Davidson Basil (2011), Społeczna i polityczna historia Afryki XX w., przeł. B. Hlebowicz, Warszawa: Wydawnictwo Naukowe PWN.

Delumeau Jean (1996), Historia raju, przeł. E. Bąkowska, Warszawa: Państwowy Instytut Wydawniczy.

Le Clézio Jean Marie Gustave (2008), Onitsza, przeł. A. Paderewska-Gryza, Warszawa: Państwowy Instytut Wydawniczy.

Le Clézio Jean Marie Gustave (2008), Afrykanin, przeł. K. i K. Pruscy, Warszawa; Wydawnictwo Cyklady.

Le Clézio Jean Marie Gustave (2010), Wojna, przeł. K. Teodorowicz, Warszawa: Wydawnictwo W.A.B.

Mbassi Atéba (2008), Identité et fuidité dans l'œuvre de Jean-Marie Gustave Le Clézio, Paris: L'Harmattan. 
Mootoosamy Vidoolah (2012), "Maurice est si loin qu'on ne peut qu'en rêver": le Paradis perdu de J.M.G. Le Clézio entre mythe et memoire, "Altre Modernità", nr 7, s. 112-125, http://riviste.unimi.it/index.php/AMonline/article/view/2140.

Onimus Jean (1994), Pour lire Le Clézio, Paris: PUF.

Panic Marija, Le continent-énigme: l'Afrique vue par les yeux de Kourouma et de Le Clézio, http://www.fabula.org/colloques/document1340.php.

Prokopiuk Jerzy (1994), Mit Raju, „Konteksty”, nr 3-4, s. 4-7.

Thibault Bruno (2009), J.M.G. Le Clézio et la métaphore exotique, Amsterdam: Rodopi. Ugochukwu Françoise (2016), L'Étranger chez Le Clézio: une exploration d'Onitsha et de L'Africain, w: A. C. Santos, M. de Jesus Cabral, L'Etranger, Paris: Editions Le Manuscrit, https://www.academia.edu/28415163/LEtranger_chez_Le_Clézio_une_ explorati_on_dOnitsha_et_de_LAfricain.

\title{
Paradise Lost or the Image of Africa in the Novels by J.M.G. Le Clézio: Onitsha and The African
}

\begin{abstract}
This article analyses the image of Africa presented in Le Clézio's novels. The author claims that a part of childhood spent in Africa determined Le Clézio as a man and writer. This experience inspired him to write two novels: Onitsha and The African creating Africa as a place of infinite freedom that puts an end to fear imposed by the war.
\end{abstract}

Keywords: paradise lost, Africa, quest, Le Clézio's works, travel 